\title{
Stakeholder engagement in the governance of marine migratory species: barriers and building blocks
}

\author{
Rachel Lynn Miller*, Helene Marsh, Claudia Benham, Mark Hamann \\ College of Science and Engineering, James Cook University, Townsville, QLD 4811, Australia
}

\begin{abstract}
Meaningful stakeholder engagement is important to collaborative decision-making and to effective polycentric governance, particularly when managing cross-scale environmental issues like those involving marine migratory species. In this paper, we explore the barriers to, and opportunities for, stakeholder involvement in the governance of threats to marine migratory species in eastern Australia, using semi-structured qualitative interviews and a focus group, as an example of the generic problem of managing migratory species within a large range state with multiple jurisdictions. Respondents identified several barriers to, and opportunities for, improved stakeholder involvement in the governance of marine migratory species, corresponding to 4 main themes: decision-making processes, information sharing, institutional structures, and participation processes. Respondents indicated that the governance system protecting marine turtles, dugongs, humpback whales, and non-threatened migratory shorebirds in eastern Australia would benefit from the introduction of new information pathways, reformed institutional structures (including environmental legislation), and improved participatory pathways for non-government stakeholders. Such changes could help harmonise the process of managing these species, leading to more effective conservation management throughout their range.
\end{abstract}

KEY WORDS: Stakeholder engagement $\cdot$ Collaborative governance $\cdot$ Marine migratory species

\section{INTRODUCTION}

Addressing the negative impact of the Anthropocene will require robust and effective environmental governance (Mace 2014, Leenhardt et al. 2015). One component of effective environmental governance involves identifying stakeholders who are affected by decision-making and involving them in the decision-making process (e.g. Graham et al. 2003, Reed et al. 2009). Identifying and involving such stakeholders should help natural resource managers reduce bias in decision-making and capture diverse values and management concerns to develop appropriate governance interventions (Dietz et al. 2003, Folke et al. 2005, Luyet et al. 2012, Benham 2017). Therefore, because stakeholders hold a

${ }^{*}$ Corresponding author: rachel.miller3@my.jcu.edu.au diverse range of values and viewpoints, capturing their different perspectives and understanding their values can assist decision-makers in making socially equitable and biologically appropriate decisions to appropriately address threats to natural resources (Graham et al. 2003, Charnley et al. 2017, Gould et al. 2017).

Effective environmental governance is often underpinned by a polycentric governance system (Graham et al. 2003, Lockwood 2010). Polycentric governance often includes actors operating at both the same level of governance (e.g. a state government interacting with other state governments) and different levels of governance (e.g. a state non-governmental organisation [NGO] interacting with an international NGO; Young 2002, Armitage et al. 
2008, Termeer et al. 2010). Polycentric governance is generally better than monocentric governance at addressing large-scale environmental management issues because a single government agency is unlikely to have the knowledge or capacity to address large-scale, complex environmental problems (Lockwood 2010, Biggs et al. 2012, Morrison 2017). Because polycentric systems involve multiple governance bodies, they also involve networks of diverse stakeholder agencies that serve as vertical (between governance levels) and horizontal (same governance level) links across jurisdictions (Olsson et al. 2007, Carlsson \& Sandström 2008, Termeer et al. 2010).

Polycentric governance systems can balance centralised and decentralised governance approaches because the governance bodies within the governance regime can organise themselves using either top-down (centralised) or bottom-up (decentralised) processes of learning and adaptation (Imperial 1999, Carlisle \& Gruby 2017, Morrison 2017). Decentralised governance involves sharing governance and decision-making responsibilities among multiple governance bodies (including non-government stakeholders; de Loë et al. 2009). Cross-scale links across governance levels can promote stakeholder engagement within the system, particularly where formal connections (e.g. legislation) between jurisdictions are weak (Miller et al. 2018).

Stakeholder engagement ranges from one-way information giving to collaboration and stakeholderled approaches (e.g. Arnstein 1969), and each form of participation has a place in environmental governance. Non-participation, also known as one-way information sharing, involves a power imbalance between stakeholder groups, and communication is often one way (Arnstein 1969, Green \& HuntonClarke 2003, Benham \& Hussey 2018). Power-holders and decision-makers aim to 'educate' or 'cure' stakeholders (Arnstein 1969, Green \& Hunton-Clarke 2003). Passive participation, such as consultation, can help government agencies meet their legislative requirements, but efforts are often tokenistic because stakeholders provide feedback or information on governance processes but are not directly involved in decision-making, and there is no guarantee that these concerns will be incorporated into a decision (Arnstein 1969). Alternatively, active participation promotes the deliberate exchange of ideas between multiple groups of stakeholders (Arnstein 1969, Rowe \& Frewer 2000, Reed et al. 2009).

When stakeholders actively participate in decisionmaking, there is often a shift from a more centralised approach to a more decentralised approach (Arnstein 1969). Stakeholders are empowered and can have real influence when they actively engage in decision-making (Arnstein 1969, Green \& Hunton-Clarke 2003). One example of active participation in natural resource governance is the co-management of natural resources. Co-management of natural resources is defined as a partnership between governing bodies and local resource users and is a type of decentralised governance that can be used to address the shortcomings associated with top-down natural resource management and lead to greater collaboration between stakeholder agencies (e.g. Berkes 2009, Nursey-Bray \& Rist 2009, Marin \& Berkes 2010).

Collaborations are a means of active stakeholder participation and can be effective at addressing policy issues, promoting the sharing of ideas and information between stakeholder agencies across various combinations of jurisdictions, and can address power balances within the governance system (e.g. Arnstein 1969, Ostrom 1986, Rowe \& Frewer 2000, Graham et al. 2003, Margerum 2008, Reed et al. 2009, Lockwood 2010). Collaborative efforts at the policy level are often high level and focused on legislation (e.g. local, state, or federal), policies, and rules that eventually influence the lower-level actions that are implemented (Margerum 2008). At lower governance levels, such as in local government areas with small human populations, collaboration is often focused on implementing action and conservation initiatives (Ostrom 1986, Margerum 2008). Cross-scale collaborations also foster innovation and the adaptation of management strategies and consequently improve the effectiveness of governance interventions (e.g. Graham et al. 2003, Barrios-Garrido et al. 2019).

Adaptive governance is a cyclical process that allows for experimentation and using the results to inform and refine governance approaches (Holling 1978, Jones 2005, 2009). Adaptive governance is often applied to complex socio-ecological problems such as environmental problems because it is more flexible than pre-determined, static management approaches (Armitage et al. 2008, Berkes 2009). Collaborative governance is an extension of adaptive governance that describes processes involving multiple governance bodies from all levels (e.g. state and federal governments, NGOs, non-government stakeholder agencies; Emerson et al. 2012). Collaborative adaptive governance is a decentralised, hybridised form of adaptive governance (Lemos \& Agrawal 2006, Plummer et al. 2013). For marine migratory species, collaborative adaptive governance can 
enable the meaningful engagement of multiple stakeholder agencies across governance scales and has the potential to harmonise the management of threats to such species (e.g. Nevins et al. 2009, Lascelles et al. 2014, Riskas et al. 2016), particularly in very large marine jurisdictions, such as in Australia.

Australia's marine jurisdiction (approximately 10 million $\mathrm{km}^{2}$ of ocean) is the third largest marine jurisdiction globally (Geoscience Australia 2019a). It is managed by 8 state and/or territory governments (up to 3 nautical miles [nmi] offshore), plus the Australian Commonwealth Government (from $3 \mathrm{nmi}$ to the edge of Australia's exclusive economic zone, Geoscience Australia 2019a,b). However, though the marine governance system is polycentric in that it is comprised of multiple governance bodies across jurisdictions (e.g. Miller et al. 2018, 2019), the governance of threats to marine migratory species in eastern Australia remains highly centralised around federal government agencies (R. L. Miller unpubl. social network data). Therefore, collaboration across jurisdictions and between government and non-government stakeholder agencies is required to manage threats to marine migratory species.

Marine migratory species migrate across jurisdictional boundaries, within Australian waters and outside of Australia, and are affected by cumulative anthropogenic threats in different jurisdictions (e.g. Meek et al. 2011, Lascelles et al. 2014, Miller et al. 2018, 2019, Gallo-Cajiao et al. 2019). Increased stakeholder participation in decision-making may help harmonise the management of marine migratory or threatened species as they move throughout their ranges.

To date, there has been minimal exploration of the governance system protecting marine migratory species in Australia (exceptions include Weiss 2011, Weiss et al. 2012). However, it is important to understand the effectiveness and limitations of current governance arrangements, including how effectively they include a diverse range of stakeholders.

Several barriers exist that can complicate stakeholder engagement in environmental decision-making, some of which we explore in this manuscript. Examples of these barriers include communication barriers (e.g. sharing information between different governance bodies; Arlinghaus 2006), capacity barriers, and resource barriers (including financial, e.g. Adger et al. 2006, Fraser et al. 2017). Proposed solutions to these barriers often arise as reforms to the barriers (e.g. more funding to address resource barriers, capacity building, Dale et al. 2016, Fox et al. 2017). Nevertheless, despite the challenges, stake- holder participation is generally viewed as beneficial to generating high-quality solutions to environmental problems (e.g. Luyet et al. 2012).

There are several frameworks that discuss the principles of inclusive, robust, and effective environmental governance (see Table 2, e.g. Graham et al. 2003, Lockwood 2010, Bennett \& Satterfield 2018). In this paper, we aim to identify the barriers to, and opportunities for, involving different stakeholder agencies, particularly non-government stakeholder agencies (e.g. industry representatives, independent researchers), in the governance of threats to marine migratory species in eastern Australia. Identifying and understanding these barriers and opportunities has the potential to improve the overall governance of threats to these species to ensure that engagement is useful and produces decisions that are socially equitable and biologically appropriate (e.g. Miller et al. 2019).

\section{METHODS}

We conducted 36 interviews (with 38 respondents) from November 2017 to October 2018 using semistructured qualitative interviews (e.g. Rose 1994, Whiting 2008) as well as a focus group (with 5 people, e.g. Patton 1990, Kitzinger 1994) with stakeholders involved in the governance of marine migratory species on the east coast of Australia (Table 1). All individuals invited to participate in an interview either worked in environmental policy and/or governance or worked in the management of threats to marine turtles, dugongs, humpback whales, and/or non-threatened migratory shorebirds in eastern Australia (Section 2.3).

\subsection{Semi-structured interview and focus group protocols}

We used a combination of purposive and snowball sampling to identify potential respondents (e.g. Patton 1990, Teddlie \& Yu 2007). We first identified potential respondents through a document analysis of 138 policy instruments protecting marine migratory species in eastern Australia (Miller et al. 2018). Potential respondents were provided with an information sheet and allowed to give informed consent or to decline an interview. At the end of each interview, we asked respondents to recommend additional experts who would have key insight into our research questions (see the Supplement at www.intres.com/articles/suppl/n043p001_supp.pdf for exam- 
Table 1. Affiliation, associated jurisdiction, and number of respondents from each agency. NGO: non-governmental organisation

\begin{tabular}{|lc|}
\hline $\begin{array}{l}\text { Stakeholder agency and } \\
\text { jurisdiction government }\end{array}$ & $\begin{array}{c}\text { No. of } \\
\text { respondents }\end{array}$ \\
\hline Agencies & \\
Commonwealth & 3 \\
Queensland & 1 \\
Queensland local government & 1 \\
New South Wales & 3 \\
Victoria & 3 \\
Tasmania & 2 \\
NGOs & \\
National & 10 \\
Queensland & 3 \\
Victoria & 1 \\
Independent researchers & \\
National & 4 \\
Indigenous & \\
Torres Strait Islander & \\
Aboriginal Australian & 1 \\
Industry representatives & 1 \\
Fisheries & \\
Ports & 2 \\
Tourism & 2 \\
\hline
\end{tabular}

ples of interview questions). We conducted most interviews by telephone but also in person and via video communication links (e.g. Skype), where appropriate. Limits to funding and the uncertain schedules of respondents affected how often we could conduct in-person interviews.

We also conducted a qualitative focus group with a Commonwealth Government agency (5 participants). Focus group participants were provided with an information sheet and informed consent forms prior to attending the focus group. We chose to use a focus group because focus groups allow the facilitator to understand (1) what the participants view as important, (2) the participants' use of language, and (3) the participants' wordviews (Kitzinger 1994). We used a pre-existing group (e.g. colleagues in the same branch of the same department) because the familiarity of the participants with each other helped them relate to each other's comments and also provided insight into environmental decision-making and the internal dynamics of the participating agency (Kitzinger 1994). Further, focus groups allow for rapid data collection, reducing field costs (Reed et al. 2009).

We designed our questions to identify barriers to, and opportunities for, involving stakeholder agencies (particularly non-government) in the governance of threats to marine migratory species. To do this, we asked interview respondents and focus group participants the following questions (for a full list of interview questions, see the Supplement): (1) What are some of the barriers to involving different levels of stakeholders (particularly non-government groups) in the policy and management of marine migratory taxa? (2) What are some of the opportunities or potential solutions to the barriers you mentioned (more specific during the focus group) that would lead to more involvement of different types of stakeholders in the policy and management of marine migratory taxa?

With permission, we recorded all interviews and the focus group. Additionally, for the focus group, a research assistant also took notes (with permission from the participants) on key discussion themes so that the facilitator could focus on facilitating the discussion. The research assistant (1) had previous experience with facilitating focus groups and semistructured interviews, (2) was provided with an information sheet before the focus group, and (3) was advised about the need for confidentiality prior to commencement.

The depth to which interview respondents provided answers to particular questions was dependent on the background and the expertise of the participant (Table 1). There was a slight variance in the questions we asked stakeholders from different agencies due to their differing expertise (e.g. government stakeholders were asked slightly different questions than independent researchers). Further, it is important to note that the roles of the respondents within their affiliated organisations likely influence and/or constrain their responses to interview questions (Newig et al. 2010, Weiss 2011).

\subsection{Data analysis}

We transcribed all interview and focus group audio and iteratively coded transcripts into themes using NVivo (Ver. 11.4.3). We used a grounded theory approach to identify key (and representative) concepts that were grounded in the data from the responses (Corbin \& Strauss 1990) and conducted interviews until we reached data saturation and no new themes emerged from the analysis (Fusch \& Ness 2015). We also assessed the concepts and themes that emerged from our data against the principles of effective natural resource governance (Table 2) (e.g. Graham et al. 2003, Lockwood 2010, Bennett \& Satterfield 2018). 


\subsection{Case studies}

We focused on Australian stakeholder agencies (national and from the east coast of Australia) involved in the governance of threats to marine turtles, dugongs, humpback whales, and 27 species of non-threatened migratory shorebirds protected under the Wildlife Conservation Plan for Migratory Shorebirds (Commonwealth of Australia 2015). We chose these taxa as case studies because they (1) are all matters of national environmental significance (MNES) listed under the Australian Environment Protection and Biodiversity Conservation Act 1999 (EPBC Act) (Commonwealth of Australia 1999), (2) move across multiple jurisdictions, and (3) are charismatic, increasing the likelihood that a diverse range of stakeholders will be concerned about their conservation (Table 3). We considered non-threatened migratory shorebirds rather than threatened migratory shorebirds because non-threatened species are protected under a single legislative instrument in Australia (Wildlife Conservation Plan for Migratory Shorebirds, Commonwealth of Australia 2015) and are also protected by international agreements between Australia and China, the Republic of Korea, and Japan (e.g. the China-Australia Migratory Bird Agreement, the Republic of Korea-Australia Migratory Bird Agreement, and the Japan-Australia Migratory Bird Agreement, respectively).

The east coast of Australia is also important in the distribution of our case study species. Six species of marine turtles live in Australian waters, with 5 species nesting on Queensland beaches (Recovery Plan for Marine Turtles in Australia, Commonwealth of Australia 2017b). The east coast of Queensland is home to several large populations of dugongs, includ-

Table 2. Principles of good environmental governance (adapted from Graham et al. 2003, Lockwood 2010, Bennett \& Satterfield 2018)

Principle of good governance

Legitimacy: (1) validity of an institution's authority for governing, (2) devolution of the governance system to the lowest level (that is still effective), and (3) integrity of an authority's means of governing

Transparency: (1) clarity of decision-making processes to all other stakeholder agencies, and (2) accessibility and availability of the information behind how and why a decision was made

Accountability: (1) delegation of and responsibility for decisions and the results of those decisions, and (2) transparency regarding if and how responsibilities have been met

Inclusiveness: clearly outlined opportunities for all stakeholders to participate in decision-making processes and the implementation of governance interventions

Fairness: (1) attention given to diverse stakeholder views, (2) equitable decisions, and (3) limited or eliminated bias in decision-making

Integration: (1) coordinated decisions within, between, and across governance levels (e.g. at the same governance level, between governance levels), and (2) harmonisation of priorities, plans, and governance interventions across governance scales

Capability: ability of stakeholder agencies to deliver their responsibilities (e.g. adequate timelines, funding, and staff levels) Adaptability: (1) incorporation of new information and knowledge into governance interventions, (2) ability to anticipate and be responsive to emerging threats and opportunities, and (3) ability to evaluate and adjust the performance of all stakeholder agencies within the governance system

Table 3. Criteria that each case study meets for listing as a matter of national environmental significance (MNES) under the Australian Environment Protection and Biodiversity Conservation (EPBC) Act 1999. In total, there are 9 MNES categories under the EPBC Act 1999

\begin{tabular}{ll} 
Case study & MNES listing under EPBC Act 1999 \\
\hline Marine turtles & Marine, migratory, threatened (category is species dependent) \\
$\begin{array}{l}\text { Dugongs } \\
\text { Humpback whales }\end{array}$ & Marine, migratory \\
Non-threatened migratory shorebirds & Migratory, cetacean, vulnerable ${ }^{\mathrm{a}}$ \\
${ }^{\mathrm{a}}$ Threatened species may be listed as critically endangered, endangered, or vulnerable under the EPBC Act 1999
\end{tabular}


ing throughout the Torres Strait Protected Zone, the Hinchinbrook Dugong Protection Area (North Queensland), Shoalwater Bay, and Moreton Bay (south of Brisbane) Marsh \& Lefebvre 1994, Marsh et al. 1999). The eastern sub-population of humpback whales migrates from feeding grounds in Antarctica to breeding grounds in the Great Barrier Reef Marine Park and Hervey Bay (Chittleborough 1965, Noad et al. 2011). Further, eastern Queensland has 3 hotspots for humpback whales: the southern Great Barrier Reef, Hervey Bay (southeast Queensland), and the Gold Coast (south of Brisbane; Meynecke et al. 2013, Commonwealth of Australia 2017a). Finally, some species of migratory shorebirds travel through the East AsianAustralasian Flyway from their breeding grounds in the Northern Hemisphere (e.g. Russia and China) to their non-breeding grounds along the east coast of Australia (Wildlife Conservation Plan for Migratory Shorebirds, Commonwealth of Australia 2015).

\subsection{Limitations}

We did not receive responses from some stakeholder agencies that may be involved in governing threats to marine migratory species because capturing the trust of stakeholder agencies often requires good rapport and long-term relationships with stakeholders, factors that we could not achieve with all of the agencies we contacted. These included some government agencies (e.g. fisheries departments), some industry groups (e.g. commercial fishers), statewide NGOs, and some Traditional Owner groups. Additionally, the Indigenous representatives we interviewed had vast experience across natural resource policy and management and spoke to us as individuals rather than as Traditional Owners representing their people, an organisation, and/or sea country (for Traditional Owners, sea country includes 'all living things, beliefs, values, creation stories, spirits and cultural obligations associated with it', Australian Government 2010, http://www.gbrmpa. gov.au/_data/assets/pdf_file/0010/ 4798/gbrmpa_ReefBeat_2010SCC_2 .pdf). Further, it is important to note that while the familiarity of the focus group participants with one another helped to validate their comments and concerns, using participants from the same government department could create an echo chamber and limit the sponta- neous sharing of ideas and the number of discussion topics (Rabiee 2004). Future research should focus on better capturing the viewpoints of the missing stakeholder agencies from this research and use focus groups with more heterogeneity where possible.

\section{RESULTS}

Respondents identified several barriers to, and opportunities for, improving the governance of marine turtles, dugongs, humpback whales, and nonthreatened migratory shorebirds in eastern Australia (Table 4, Fig. 1). These barriers and opportunities fell under 4 main themes, discussed below: (1) decisionmaking processes, (2) information-sharing processes, (3) institutional structures, and (4) participatory processes. Several of the opportunities identified in this paper arise from reforms to reduce the barriers identified by respondents.

\subsection{Decision-making processes}

Respondents identified several barriers to, and opportunities for, improving the decision-making processes that affect and influence stakeholder involvement in the governance of threats to marine migratory species in eastern Australia. This theme encompasses characteristics that describe decision-making within the governance regime, including power distribution and the ability to make evidence-based decisions within the system. Respondents from all stakeholder

Table 4. Barriers to stakeholder involvement in the good governance of threats to marine turtles, dugongs, humpback whales, and migratory shorebirds on the east coast of Australia. These barriers are non-exhaustive but are representative of multiple responses from participants of the semi-structured qualitative interviews and the focus group. Shaded boxes indicate how a particular barrier influences a principle of good environmental governance. The opportunities discussed in this paper arise from reforms to reduce these barriers

\begin{tabular}{|lllll|}
\hline \multirow{2}{*}{$\begin{array}{l}\text { Principle of } \\
\text { good governance }\end{array}$} & $\begin{array}{c}\text { Decision- } \\
\text { making } \\
\text { processes }\end{array}$ & $\begin{array}{c}\text { Information- } \\
\text { sharing } \\
\text { processes }\end{array}$ & $\begin{array}{c}\text { Institutional } \\
\text { structures }\end{array}$ & $\begin{array}{c}\text { Participatory } \\
\text { processes }\end{array}$ \\
\hline Legitimacy & & & \\
Transparency & & & \\
Accountability & & & \\
Inclusiveness & & & \\
Fairness & & & \\
Integration & & & \\
Capability & & & \\
Adaptability & & & \\
\hline
\end{tabular}




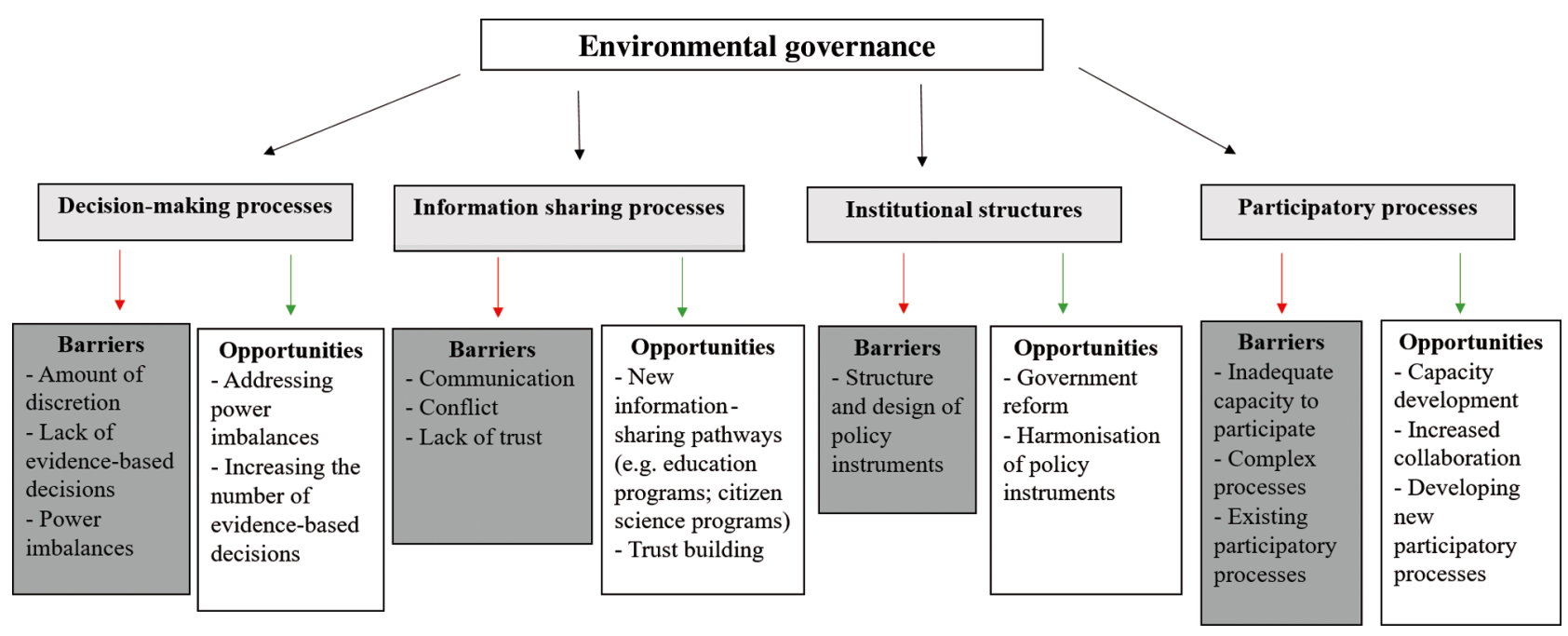

Fig. 1. Key themes that emerged from the responses of participants in the semi-structured interviews and the focus group. Dark grey boxes represent barriers to the corresponding theme, while white boxes represent opportunities for improving stakeholder involvement in the governance of threats to marine migratory species in eastern Australia. All barriers and opportunities represent responses from multiple participants

groups identified the amount of discretion available to decision-makers, a lack of evidence-based decisions, and power imbalances as key barriers to the legitimacy and accountability of this governance system.

A Commonwealth Government respondent suggested that highly centralised decision-making was a barrier to the legitimacy and accountability of the governance system, saying:

The barriers might be something as simple as political interests (in that) the government (...) might want to go in a particular direction with regard to the management of a particular species (...) that might be different from a group (...) that has a particular view. One of the things that people have to fundamentally understand about working with a government organisation is that you are there to do the business of the government of the day.

This response indicates that decision-making is likely to be directed by the agenda of the government in power (e.g. a conservative government is likely to have different approaches to environmental management than a progressive government).

An extension of centralised decision-making and another barrier to the legitimacy of the governance system is the amount of discretion available to state and federal environmental ministers as decisionmakers. A respondent from an environmental NGO suggested that decision-makers have a high amount of discretion, stating '(...) (decision-making is) so subject to the vagaries of who is currently in power that (...) (though) the intent of the legislation is great, the interpretation of the legislation is entirely flexi- ble'. A respondent from a state government agency expanded on this discretion in the context of evidence-based decisions (or the lack thereof) and the effect these decisions have on the legitimacy and accountability of the governance system:

We have a stretch of coast where horse trainers like to train their horses. That really angered local conservationists and there (is) a massive conflict there (between horse trainers and conservationists). (...) The draft plan came out with a recommendation to continue to allow that (horse training), which, (...) all the evidence suggests that it (is) not good for (shorebirds and biodiversity). (...) That (is) a really good example of where we (...) despite the evidence, don't make the right decisions.

Some respondents $(n=8)$ suggested that the following changes could increase the accountability and legitimacy of decision-making: (1) reduce the discretion of decision-makers, (2) involve decisionmakers in the research process, and (3) include lower-level governance bodies in decision-making (discussed in Section 3.4).

\subsection{Information-sharing processes}

Several respondents $(n=14)$ from all stakeholder groups cited information-sharing processes as a barrier to the transparency, accountability, and adaptability of the governance system mitigating threats to marine migratory species (Table 4). Information-sharing processes include existing pathways of informa- 
tion sharing and communication between stakeholder agencies within the governance regime (e.g. the communication of research, communication of decisions, trust). Some respondents $(n=3)$, including state government respondents and independent researchers, suggested that different timelines and cultures hinder information sharing between researchers and decision-makers, with one independent researcher saying, 'decision-makers, when they need evidence, they need it (now) and scientists might not be willing to share it until it (...) (has) gone through peer review'. Another independent researcher noted that information flow can limit a decision-maker's ability to make appropriate decisions, stating, '(...) often the right people do (not) have the information they need to have to apply the rules (...) to a particular decision'.

A respondent from the focus group expanded on this barrier to information flow between scientists and decision-makers, saying 'there (can be) an attitude amongst academics that once they (have) published, it (is) (...) the policy officer's responsibility to know about it'. Further, '(policy officers and scientists) do (not) speak the same language. Scientists (often) can (not) speak to policy officers and policy officers can (not) speak to a scientist'.

This barrier is not limited to information sharing between researchers and government officials. A state government respondent stated, 'if you do (not) work for government, you (can) view government with disdain and suspicion,' indicating that a lack of communication can lead to misunderstandings and mistrust between government and non-government stakeholder agencies.

To address some of the information-sharing barriers and improve the transparency, accountability, and adaptability of the governance system, an independent researcher suggested that better engagement with researchers and decision-making bodies could be a solution, saying:

Our model is to try and work with people who are making decisions and making policies around migratory species management. So, what we try to do and what we have done over the years is form good relationships with people charged with managing these species to try and understand the kinds of questions that they (are) struggling with and want answers to and to understand what pieces of scientific information they would find most helpful.

A Commonwealth Government respondent suggested developing a model for marine migratory species, similar to the Cooperative Research Centres (CRCs) that existed for the Great Barrier Reef, would be beneficial, saying:
The model I saw that worked best was when there were the CRCs for the Reef. You actually had end-user task associates linked up with the scientists. And so, you actually had the two-way information flow. The scientists understood what management did and managers understood the limitations of trying to get that information.

A respondent from an NGO suggested '(...) the government needs to work harder and invest much more in engaging communities at the local level' to improve communication between the government and lower-level, non-government stakeholder agencies. Another respondent, from local government, suggested that communicating the results of decisions and how feedback is used in decisionmaking can help build trust and transparency, saying, 'feedback (from decision-makers), having that circular approach where stakeholders (who have been) engaged and giving their opinions, to know where those efforts have been actioned (to make a decision)'.

Better use of technology can also improve information sharing. A state government respondent suggested that 'very simple things like a Facebook page would be great' to coordinate information sharing, while an industry respondent discussed collating information in a central location, such as a central data repository, could bring together the work of ' (...) multiple people working on research (of a particular species or issue)'.

\subsection{Institutional structures}

Various respondents viewed institutional structures (e.g. legislation, statutory requirements) as an impediment to stakeholder involvement in the governance of marine migratory species (Table 4). Institutional structures (e.g. legislation and other policy documents [e.g. management plans] and/or policy processes that support governance and decisionmaking within the governance regime) within the governance regime were viewed by various stakeholder agencies as an impediment to stakeholder involvement in the governance of marine migratory species. Several respondents $(n=8)$ cited the EPBC Act 1999 and other environmental legislation protecting marine migratory species as a barrier to the legitimacy, fairness, integration of decisions across multiple governance levels, and adaptability of the governance regime mitigating threats to these species in eastern Australia. A state government respondent argued that existing legislation and policy 
instruments are not designed to adapt with a changing environment, saying:

(...) I (am) constantly arguing that 'no, we can (not) look at where that species has been, we need to predict where it (is) going to be' and create pathways for (those changes). It fields up with climate change and population recovery that habitat that we (...) have never considered to be useful for that species is changing before our eyes. And we (are) just not being flexible enough to allow that to happen.

Other respondents, including NGO, state government, and independent research respondents, expressed concern about the limited ability to integrate decisions across a large scale, primarily in regard to the inability to assess cumulative impacts. One NGO respondent said:

A shortcoming of the legislation as I see it is we protect big sites but not little sites. (...) If (there are) hundreds of farms and pastoral leases around Australia and damage to every wetland in every property is happening, it can have very substantial effects on shorebirds.

Additionally, several respondents $(n=10)$ expressed concern that legislation between jurisdictions is not harmonised to protect marine migratory species across their range. A respondent from a state government agency compared this situation to the common assessment method (CAM) used to harmonise threatened species listing at state and Commonwealth levels:

(...) The CAM (has) been quite interesting because it (has) forced us in a way to consider that. But, (...) the legislation is only one element. In terms of policymaking, there has (not) been (...) a very strong driver to bring states together to come up with some kind of consistent approach to the conservation of migratory species.

An independent researcher expanded on the lack of harmonisation between jurisdictions, saying, 'we (...) have these multiple layers of government (that) drive both inefficiencies, but also inconsistencies in policies, which will forever cause issues'.

Other respondents, including state government, NGO respondents, and independent researchers, described an unofficial hierarchy of species prioritisation under the EPBC Act 1999. A state government respondent described the hierarchy in terms of approvals for actions that may have a significant impact on an MNES, saying 'there are lots of (listed) migratory species (...) and that (listing as a migratory species) has less weight (than threatened species listing), generally, whether it is formally or informally in decisions'. This point was further illustrated by a respondent from the focus group, who stated:
A particular project can have multiple triggers. There could be a critically endangered bird and a migratory dolphin could trigger. They (are) not any less important, but that said, usually the critically endangered species will attract more attention during the assessment.

Several respondents $(n=5)$ also cited the mandatory consultation period under the EPBC Act 1999 as a barrier to involving non-government stakeholders in the governance of threats to marine migratory species. One NGO respondent said, 'public consultation is used (...) as a "tick the box" exercise in $99 \%$ of cases (because consultation is mandatory). (...) So, generally, (...) (bureaucracy) treats it (consultation) as a procedural exercise'.

Several respondents $(n=9)$ suggested governance reforms to improve the legitimacy, fairness, integration of decisions across multiple governance levels, and adaptability of the governance regime mitigating threats to marine migratory species in eastern Australia. Some reforms included complete government overhauls, with a respondent from an NGO stating, 'we need a reset on environment policy and a new political will, much more resources going to the environment, and we need new laws'.

A state government respondent also recommended harmonising legislation, saying 'I think (a solution) would be pulling away state legislation, (and) making them (the states) come into line with Commonwealth legislation'. Another (industry) respondent expressed the need for flexibility to govern threats to marine migratory species, saying, '(...) (have) a continuous improvement process (...) (to) get new information to refine the (decision-making) process'. Further, some respondents $(n=8)$ suggested revising the EPBC Act 1999 and other environmental legislation to '(...) have (...) joint state-interstate policy, that would (address) cumulative impacts and collaborative governance up and down the states', would help harmonise legislation and address the threats that marine migratory species may face across their range. The EPBC Act 1999 is currently undergoing statutory review (as of June 2020).

\subsection{Participatory processes}

Several respondents $(n=26)$ cited participatory processes within the governance regime as a barrier to the legitimacy, transparency, inclusiveness, fairness, integration, and capability of the governance regime mitigating threats to marine migratory species (Table 4). The participatory process is the means 
by which government and non-government stakeholders can participate in developing and implementing governance interventions (e.g. the capacity and the complexity of allowing stakeholder agencies to participate in governance). For example, respondents from all stakeholder groups identified capacity (e.g. appropriate timelines, adequate resources) as a barrier to stakeholder involvement in the governance of marine migratory species in Australia (Fig. 1), with 1 independent researcher saying:

(...) There are capacity inequities. The capacity of Traditional Owners, for example, to be genuinely comanaging turtles/dugongs with societal government is actually extremely poor. That (is) an example where you would say they are connected and participants in that governance system, and resource users, but their capacity to be in a genuine co-management framing is quite low.

An independent researcher stated '(...) I think that the Commonwealth departments actually do try very hard to do (consultation with stakeholders), but I (am) not sure the resources provided are sufficient to allow that to happen properly'. Respondents from the focus group explained 'our ability to actually talk to everyone is completely hamstrung by our resourcing to do so. We by no means came even close to talking to everyone who was relevant in an effective way'. Insufficient resources may be particularly limiting when engaging Indigenous stakeholders who live in remote areas across Australia.

A respondent from an environmental NGO further emphasised the capacity barrier for non-government groups, particularly for the general public, saying:

We (are) a professional conservation organisation, so it (is) our job to engage with these processes, but we are very small and there (are) only so many submissions that we can do in a year. (...) If we (are) struggling as a professional conservation organisation, the general public and people who are local to developments (...) you can imagine that their capacity would be really difficult to try and do their full-time job with a couple of kids and fight the development down the road at the same time.

Several respondents $(n=8)$ identified the complexity (e.g. technical language) of participatory processes as another barrier, primarily to the involvement of non-government stakeholders in the governance of marine migratory species (Fig. 1). A state government respondent also said:

I think that we (are) increasingly moving into a space where it (is) difficult for those groups with less capability and capacity to have an informed view on policy development. (...) Every document you read gets bigger and more complicated and it (is) just getting harder.
To assist stakeholders with overcoming the barriers of effectively participating in the governance of threats to marine migratory species, state government respondents, independent researchers, and an Indigenous respondent emphasised the importance of education. One independent researcher said:

It (is) about giving them (non-government stakeholders) the education and training to understand where the actual influence points are. (...) Finding a local policy officer at a lower level, they (are) the ones running the briefs going up the line, so influencing them is going to have far more impact.

An industry respondent suggested that access to material in Australia to be able to make informed responses is limited and could be a means to improve the participatory processes of the governance regime, saying ' (...) I think creating material in an accessible way is a barrier. (Currently) it is very scientific, it (is) very dense with information, (and) people do (not) understand it'.

Some respondents $(n=2)$ suggested increasing the use of technology could improve cross-jurisdictional collaboration and reduce the resources needed to collect and integrate diverse viewpoints. One example of using technology to connect stakeholder agencies could be through online-based video communications (e.g. Skype).

\section{DISCUSSION}

Respondents from all stakeholder agencies emphasised the need for reforming decision-making processes, improving information sharing, reforming institutional structures, and developing more transparent and simpler participatory pathways as a means of improving the overall governance of marine turtles, dugongs, humpback whales, and nonthreatened migratory shorebirds in eastern Australia (Table 4, Fig. 1). Further, our findings are not limited to marine migratory species in eastern Australia, and may help other jurisdictions identify and anticipate issues that may arise from managing threats to largescale natural resources, including how to navigate barriers to stakeholder engagement appropriately and systematically.

\subsection{Decision-making processes}

Like many other multi-level, polycentric governance systems, Australia has a primarily centralised govern- 
ment, and the Commonwealth Department of Agriculture, Water, and the Environment (formerly known as the Department of the Environment and Energy) ultimately implements the decisions for environmental issues affecting MNES as directed by the federal minister for the environment (Margerum 2008, Garmestani \& Benson 2013). The current Australian Government (in 2020) believes in a lean government and minimal interference of the government in private affairs (Liberal Party of Australia 2019). This philosophy is likely to influence the decisions of the current Commonwealth Minister for the Environment, especially as business and economic interests tend to outcompete environmental interests (Tear et al. 2005).

The Australian Commonwealth Government's imperative to manage non-threatened migratory species results from Australia being a signatory to relevant international agreements (e.g. the Convention on Biological Diversity, Hawke 2009). Individual states and territories within Australia do not have the legislative power to list non-threatened migratory species (Department of Agriculture, Water, and the Environment pers. comm.), limiting the federal government's ability to devolve decision-making and potentially inhibiting the co-management of marine migratory species in eastern Australia.

Co-management of marine migratory species has the capacity to be successful, as shown in UK territories in the Caribbean (e.g. Campbell et al. 2009), Mexico (e.g. McCay et al. 2014), and Africa (e.g. Cinner et al. 2012). Co-management is largely comprised of relationships between the community and the government (e.g. Campbell et al. 2009). For marine migratory species in Australia, the most advanced example of decentralised governance primarily occurs through the development of co-management agreements, called Traditional Use of Marine Resources Agreements (TUMRAs), between the Great Barrier Reef Marine Park Authority (GBRMPA) and Traditional Owner groups throughout northern Australia (GBRMPA TUMRAs). Such co-management has developed because of the native title rights of Traditional Owners (e.g. Native Title Act 1993) 1 1.2. However, though the development of TUMRAs shows that a government agency may be willing to address power imbalances in decision-making, the government may still maintain the final power to choose the knowledge that is incorporated into decisions (Zurba 2009).

Policymakers should make decisions that reflect the best interest of their organisation and are appropriately evidence based (Vilkins \& Grant 2017). Much of the evidence incorporated into decisions is based on internal information that comes from colleagues within the relevant government department or from other state and Commonwealth Government agencies (Head et al. 2014). However, solely relying on intra- and interdepartmental information to make a decision undermines the legitimacy of the governance regime, as there may be limited means of determining the validity of a decision, and there are power imbalances in this approach (Head et al. 2014). Therefore, as discussed by some respondents, scientific research is also important to decision-makers for making evidence-based decisions, potentially improving the legitimacy and accountability of the decision-making processes within the governance regime (see Section 3.2, Head et al. 2014, Vilkins \& Grant 2017). However, for policymakers to make biologically and socially appropriate decisions, information and differing worldviews (including traditional ecological knowledge) must be easily accessible to decision-makers, and there should be clear, 2-way communication between all stakeholder agencies when developing future policies and management plans.

\subsection{Information-sharing processes}

Stakeholder agencies involved in natural resource governance in Australia have previously asked for better access to environmental data and information to encourage the Commonwealth environment department to be more transparent (Hawke 2009). Our results support previous findings from other largescale natural resource governance regimes (e.g. Hawke 2009, Sunderland et al. 2009, Lockwood 2010, Craik 2018, Barrios-Garrido et al. 2019) and indicate that developing and implementing clear communication pathways can (1) promote the development of future collaborations between different stakeholder agencies, (2) potentially reduce conflict, and (3) increase the transparency, accountability, and adaptability of the overall governance regime.

Introducing an information-sharing system could be one solution for achieving transparency within the governance system. Any information-sharing system should have a 2-way flow of information that is rele-

\footnotetext{
$\underline{1}$ Australia did not recognise the rights of Aboriginal Australians and Torres Strait Islanders to their land (as defined by cultural customs and laws) until 1992 after the landmark native title case Mabo vs. Qld (No. 2)

$\underline{2}$ Traditional Owner groups have exclusive rights to the intertidal area of $80 \%$ of the Northern Territory coastline (Gumana v Northern Territory 2007)
} 
vant and accessible to each stakeholder agency (e.g. government-sharing information with other stakeholder agencies and vice versa; Arnstein 1969, Lockwood 2010). The CRC for the Great Barrier Reef was an example of an effective information-sharing system that promoted collaboration between stakeholders across governance levels and produced policy-relevant research (Woodley et al. 2006). Currently, the Commonwealth Department of Agriculture, Water, and the Environment operates the Species Profile and Threats Database (SPRAT), which outlines species life histories, threats, and conservation statuses. However, these profiles do not provide insight into specific actions or activities conducted by stakeholder agencies throughout the range of the species (e.g. who is doing what, Miller et al. 2019). Further, the Commonwealth Government compiles the information available in SPRAT profiles, and there is no link for other stakeholder agencies to upload information.

Introducing an information-sharing database, where industry, government agencies, and academics can upload datasets, research outputs, and summaries, would be beneficial to the governance of marine migratory species in eastern Australia and to other largescale natural resource governance regimes. Having a data and information repository that is easily accessible for all stakeholder agencies could also address the silo effect and fragmentation occurring within the governance regime protecting marine migratory species in eastern Australia (Hawke 2009). Opening avenues to improve future information sharing and communication could also (1) promote collaboration between jurisdictions, (2) produce decisions that are biologically and socially appropriate, and (3) aid in educating nongovernment stakeholder agencies in policy and protocol to help them better navigate complex governance processes (Sunderland et al. 2009, Pietri et al. 2015, Hays et al. 2019) (see Section 4.4). Successful development of an information-sharing database in Australia could be adapted and used to manage marine migratory species moving through other large marine jurisdictions, including the Coral Triangle and the Caribbean (e.g. Barrios-Garrido et al. 2019).

\subsection{Institutional structures}

Australia has an international reputation as a key player in environmental governance (Bührs \& Christoff 2006). However, several respondents cited Australia's current government system (nationally) as a barrier to the appropriate governance of marine migratory species. Some respondents suggested that the Australian Government's Department of Agriculture, Water, and the Environment is likely to prioritise environmental issues under a hierarchy based on threatened species listing rather than any other MNES. Threatened species listing drives the development of management tools (e.g. recovery plans and conservation advices) for natural resource governance in Australia (Hawke 2009, Walsh et al. 2013, McDonald et al. 2015). Therefore, a threatened species with a smaller range may receive more government conservation support than a threatened or nonthreatened migratory species. Additionally, there may be other species or situations with more urgent need for conservation interventions than migratory species (e.g. the 2018-2019 fish kills in the MurrayDarling River basin [Murray-Darling Basin Authority 2019] or the 2019-2020 Australian bushfires). Australia already underfunds biodiversity conservation when compared to other developed countries (Waldron et al. 2013, 2017, Threatened Species Scientific Committee 2018), and it is unlikely that environmental decision-making will be prioritised over other areas of public policy in the foreseeable future (Tear et al. 2005) unless Australia's current system of government is reformed.

Suggestions of governmental reform are not new and have been gaining momentum in recent years. In 2018, the Parliament of Australia requested submissions to the Senate's Environment and Communications References Committee inquiry into Australia's faunal extinction crisis (see https://www.aph. gov.au/Parliamentary_Business/Committees/Senate/ Environment_and_Communications/Faunalextinction/ Submissions). The submissions of several stakeholder agencies, including state agencies, Commonwealth committees, and NGOs, emphasised the need for reforming Australia's environmental policy (e.g. Humane Society International 2018, Queensland Conservation Council 2018, Threatened Species Scientific Committee 2018). While not all of our case study taxa are nationally threatened in Australia (e.g. dugongs and migratory shorebirds protected under the Wildlife Conservation Plan for Migratory Shorebirds, Commonwealth of Australia 2015, Table 2), each of them would benefit from reformed environmental legislation, in view of the weaknesses in their protection resulting from the lack of policy coherence and highly centralised decision-making within the governance system (Miller et al. 2018).

The EPBC Act 1999 is currently under review (in 2020, Section 522A of the EPBC Act 1999, see https:// epbcactreview.environment.gov.au/get-involved). Resultant reform of the EPBC Act 1999 provides an 
opportunity to improve the fairness, integration, and coherence of legislation protecting marine migratory species and other MNES in Australia. We suggest that one means of improving the fairness of the governance system and integrating diverse stakeholder viewpoints could be through the revised EPBC Act 1999 requiring the establishment of representative steering groups to advise on the development and implementation of each management plan (described in depth in Miller et al. 2019). However, because truly representative steering groups can be large and counterproductive, representativeness can be achieved using carefully selected expertise (e.g. Commonwealth Fisheries Marine Mammal Working Group). This expertise can include stakeholder agencies familiar with regional approaches to managing large-scale natural resources (e.g. natural resource management bodies, government agencies) as well as agencies with expertise in operating within a nongovernment environment (e.g. independent researchers, NGO representatives, Miller et al. 2019).

Another change to the EPBC Act 1999 and environmental legislation in eastern Australia more broadly could be through outcomes-based legislation instead of prescriptive legislation to address the discretion issue in environmental decision-making as identified by our respondents. Outcomes-based legislation can provide flexibility to decision-makers and practitioners when developing and implementing decisions (Macintosh 2010). Outcomes-based management approaches have been proposed in Australia for biodiversity conservation (e.g. Byron et al. 2014) and the Great Barrier Reef (e.g. Bell 2016) as well as abroad in New Zealand (Sutton 2004). Several respondents from our study viewed the discretion available to decision-makers (including the Commonwealth environment minister) as a barrier to good environmental governance. Thus, focusing on achieving specific environmental outcomes (that could be agreed upon by the members of the steering groups described above, e.g. limiting the disturbance of critical habitats for resting shorebirds) could be one means to address the discretion barrier and still achieve the desired environmental outcomes.

Some of our respondents suggested that a lack of harmonisation and integration of viewpoints in environmental legislation also reflected a silo effect between different jurisdictions charged with the governance of marine migratory species throughout their range. This silo effect and lack of integration across governance scales is not limited to the governance of threats to marine migratory species (e.g. Mostert et al. 2007, Dale et al. 2013). The silo effect can reinforce fragmentation within a governance regime, limiting the types of knowledge used (and available) for decision-making (see Sections 4.1 and 4.2 ), and affect the overall integration of the governance system (de Loë et al. 2009, Dale et al. 2013, Potts et al. 2016). Changes to legislation are likely to be incremental, as governmental reform is an expensive process (Garmestani \& Benson 2013), so it is important to introduce ways to improve coherence within the governance system protecting marine migratory species in eastern Australia and other cross-scale natural resource management issues. Our findings agree with results from other governance regimes (e.g. Mees et al. 2019) and identified better integration of lower-level, non-government stakeholder agencies into governance processes and improved participatory pathways as one means to improve coherence (described in more detail in Section 4.4).

\subsection{Participatory processes}

Several respondents indicated that the governance of threats to marine migratory species may not be collaborative or effective. Respondents indicated that resources are a limiting factor of stakeholder participation within the governance of threats to marine migratory species in eastern Australia. This finding is not unique to governing threats to marine migratory species and applies to other natural resource governance regimes more broadly (e.g. Szabo et al. 2016, Woinarski et al. 2017). Limited resources may mean that government departments must focus on the core business of their department as dictated by the government in power using the resources they already have (Fraser et al. 2017).

A potential way to increase the resources available for mitigating threats to marine migratory species in eastern Australia, and thus improve the future capacity and capability of the governance system, could be through the use of bridging organisations. Bridging organisations have been effective in the governance of marine conservation in Indonesia (e.g. Berdej \& Armitage 2016) and the USA (e.g. Mountjoy et al. 2014). A bridging organisation could increase the available staff to work on an issue if grants or funding are channelled to bridging organisations involved in mitigating threats to marine migratory species in Australia (e.g. as the Great Barrier Reef Foundation does for the GBRMPA). These bridging organisations could then help lower-level governance bodies, who may not currently have the resources, participate in 
future decision-making and management interventions, such as monitoring (e.g. Australian Research Council Linkage Grants; Howes 2008, Gallo-Cajiao et al. 2019).

Due to Australia's large size and small human population, a more coordinated monitoring approach may help with understanding the threats to and conditions of distinct populations of marine migratory species throughout their range (e.g. nesting turtles on beaches in Queensland, migratory shorebird populations in coastal wetlands in Victoria; Hansen et al. 2018, Wintle 2018, Hays et al. 2019). Coordinated monitoring could then link sightings and information across jurisdictions. This is particularly important when managing marine migratory species, as some species, such as turtles nesting on local beaches, cross local, state, and Commonwealth boundaries with their movements (Weiss 2011). A coordinated monitoring system is being developed through the Reef 2050 Integrated Monitoring and Reporting Program to monitor MNES found within the Great Barrier Reef World Heritage Area (GBRWHA). For marine migratory species, it would be beneficial to develop and implement a coordinated monitoring system that extends beyond the GBRWHA and into other natural resource management regions throughout the range of these species (Humane Society International 2018).

We suggest that a coordinated monitoring system could be facilitated through better engagement with research organisations. Independent researchers, such as scientists affiliated with universities, have a unique place in socio-ecological systems in that they may be well positioned to serve as a bridge between stakeholder agencies (e.g. Weiss et al. 2012, Cvitanovic et al. 2017). There may be no other governance body equipped to facilitate linkages between governance scales, as many other groups, such as NGOs, have limited capacity to conduct research of their own and contract independent researchers to do research (Liverman 2004). As indicated by some respondents, increasing the capacity of researchers, such as through improved funding, may assist with the training of other non-government stakeholders, such as community groups, who wish to participate in governance of marine migratory species through citizen science programs (e.g. monitoring programs). The CRC for the Great Barrier Reef served as a bridging organisation between policymakers and researchers; however, this program is no longer operating. Actively involving bridging organisations and increasing the capacity of these organisations (or stakeholder agencies) could increase overall capac- ity of the network and link different stakeholder agencies throughout eastern Australia (Weiss 2011).

Our respondents suggested that using technology, such as online video communication links, could promote future cross-scale collaborations. This is becoming more feasible as reliable internet access is increasingly becoming available in remote areas of Australia, especially in areas with local or state government offices or schools. Anecdotal evidence arising from adaptations to the COVID-19 pandemic has already demonstrated that the need to travel for meetings has been substantially reduced due to improved technology. Using technology could also reduce or eliminate the need for Traditional Owners (as well as other stakeholder agencies), who may be unable to participate effectively in the governance of marine migratory species due to capacity inequities, to travel for meetings.

Several respondents identified complex processes as a barrier to the participation of non-government stakeholder agencies. To date, complexity is a barrier that has been underexplored in the literature, thus making our results unique. Some respondents indicated that the complex consultation process required by the EPBC Act 1999 hinders the ability of nongovernment stakeholders to participate effectively in the governance of threats to marine migratory species. Much of this process relies on written submissions that address the document under review, requiring stakeholders to be well informed and familiar with that document (Antonson 2014). Creating policy instruments that allow a diverse range of stakeholders to become well informed about the document may be difficult, as the Commonwealth Department of Agriculture, Water, and the Environment needs to consider multiple values and use specific language within legislation and management documents (Department of Agriculture, Water, and the Environment pers. comm.). Further, using written submissions as the primary form of consultation limits the ability of disadvantaged stakeholders to engage (e.g. low literacy), especially stakeholders whose knowledge does not readily translate to fit the western concept of governance (e.g. Indigenous groups; Casimirri 2003, Benham 2017). Additionally, a document is usually not released for consultation until it is near completion. Thus, any resultant changes from consultation are usually technical, and some comments provided by stakeholders may not be incorporated into the final version of the document because they are deemed out of scope.

Some respondents considered that there is no transparent feedback mechanism that helps non- 
government stakeholder agencies understand where their feedback has been implemented (or not) into policy instruments. Our results align with reviews of the EPBC Act 1999 as it applies to other natural resource governance regimes (e.g. Hawke 2009, Craik 2018). It is important to note that comments on some EPBC policy instruments and documents are posted publicly on the Department of Agriculture, Water, and the Environment's website (e.g. Engage early-guidance for proponents on best practice Indigenous engagement for environmental assessments under the EPBC Act, https://www. environment.gov.au/epbc/consultation/engage-earlyindigenous-engagement), while most are not. Due to this lack of transparency and consistency, the EPBC consultation process is perceived as tokenistic. The upcoming revision of the EPBC Act 1999 or any other overhaul to Australia's environmental legislation (discussed in Section 4.3) should consider more inclusive approaches to stakeholder engagement and reduce the complexity for nongovernment stakeholders to participate effectively in the governance of marine migratory species in eastern Australia (e.g. Mostert et al. 2007, Hawke 2009).

Some potential solutions for helping non-government stakeholders navigate complex governance processes include education and information sharing (discussed in Section 4.2). Bridging organisations could play a role here, particularly if the bridging organisation is familiar with the policymaking processes (e.g. an academic or NGO; Oliver \& Cairney 2019). These bridging roles could also be fulfilled by public servants or by using appropriately trained individuals or organisations familiar with the policy processes (as described by Craik 2018 for Australia's agricultural sector). Bridging organisations that are familiar with the policymaking processes can help other non-stakeholder agencies understand the difference between policy and management and identify areas where stakeholders may have the most influence in future decision-making (Evans \& Cvitanovic 2018, Oliver \& Cairney 2019).

Creating informal (e.g. pamphlets or brochures), non-formal (e.g. structured workshops or educational presentations), and/or formal (e.g. courses, tertiary education programs) education interventions may help provide non-government stakeholder agencies with the information they need to effectively participate in environmental governance (Maarschalk 1988, Tamir 1991, Eshach 2007). An example of such an educational program is the New Zealand Department of Conservation's implementation of the Envi- ronmental Education for Sustainability Strategy (2017-2027) (Department of Conservation 2017). This program aims to educate and support government agencies in developing pathways to encourage the participation of non-government stakeholder agencies in addressing environmental issues, including how to engage with and inform environmental governance. Australia does not yet have these explicit guidelines for government or non-government agencies for protecting marine migratory species. However, developing and implementing programs (either formal or non-formal) or educational materials (informal) that can help non-government stakeholder agencies effectively participate in the governance of marine migratory species may require fewer changes in institutional structures than other reforms (Section 4.3).

\section{CONCLUSIONS}

The governance of marine migratory species in eastern Australia would benefit from the introduction of new information pathways, reformed institutional structures (including changes to environmental legislation), and improved participatory pathways for non-government stakeholders. Our results highlighted some well-studied barriers to stakeholder engagement and identified complexity as a new, underexplored barrier that may apply to environmental governance more broadly. Examples of where our results may be useful include collaboratively governing threats to marine migratory species with large ranges, including species occurring within and outside of national waters (e.g. species with ranges throughout the Coral Triangle and the Caribbean).

Acknowledgements. This study was conducted under Human Ethics Permit H6876 granted by James Cook University. R.L.M. is supported by an International Postgraduate Research Scholarship from James Cook University. We thank all of the respondents for participating in this study and V. Pilbeam for assisting with note taking during the focus group.

\section{LITERATURE CITED}

Adger WN, Brown K, Tompkins EL (2006) The political economy of cross-scale networks in resource co-management. Ecol Soc 10:9. www.ecologyandsociety.org/vol10/ iss2/art9/

Antonson H (2014) Public participation and written submissions: a transport infrastructure planning case study. Transp Res Part A Policy Pract 70:59-66

Arlinghaus R (2006) Overcoming human obstacles to conservation of recreational fishery resources, with emphasis on central Europe. Environ Conserv 33:46-59 
Armitage D, Marschke M, Plummer R (2008) Adaptive comanagement and the paradox of learning. Glob Environ Change 18:86-98

Arnstein SR (1969) A ladder of citizen participation. J Am Plann Assoc 35:216-224

Barrios-Garrido H, Wildermann N, Diedrich A, Hamann M (2019) Conflicts and solutions related to marine turtle conservation initiatives in the Caribbean basin: identifying new challenges. Ocean Coast Manage 171:19-27

Bell J (2016) Implementing an outcomes-based approach to marine biodiversity offsets: lessons from the Great Barrier Reef. Australas J Environ Manage 23:314-329

Benham CF (2017) Aligning public participation with local environmental knowledge in complex marine socialecological systems. Mar Policy 82:16-24

Benham CF, Hussey KE (2018) Mainstreaming deliberative principles in environmental impact assessment: current practice and future prospects in the Great Barrier Reef, Australia. Environ Sci Policy 89:176-183

Bennett NJ, Satterfield T (2018) Environmental governance: a practical framework to guide design, evaluation, and analysis. Conserv Lett 11:e12600

Berdej SM, Armitage DR (2016) Bridging organizations drive effective governance outcomes for conservation of Indonesia's marine systems. PLOS ONE 11:e0147142

Berkes F (2009) Evolution of co-management: role of knowledge generation, bridging organizations and social learning. J Environ Manage 90:1692-1702

Biggs R, Schlüter M, Biggs D, Bohensky EL and others (2012) Toward principles for enhancing the resilience of ecosystem services. Annu Rev Environ Resour 37: 421-428

Bührs T, Christoff P (2006) 'Greening the antipodes'? Environmental policy in Australia and New Zealand. Aust J Polit Sci 41:225-240

Byron N, Craik W, Keniry J, Possingham H (2014) A review of biodiversity legislation in NSW: final report. Prepared by Independent Biodiversity Legislation Review Panel for State of NSW and the Office of Environment and Heritage, Sydney. State of NSW and the Office of Environment and Heritage, Sydney

* Campbell LM, Silver JJ, Gray N, Ranger S and others (2009) Co-management of sea turtle fisheries: biogeography versus geopolitics. Mar Policy 33:137-145

Carlisle KM, Gruby RL (2017) Polycentric systems of governance: a theoretical model for the commons. Policy Stud J 00:1-26

Carlsson L, Sandström A (2008) Network governance of the commons. Int J Commons 2:33-54

Casimirri G (2003) Problems with integrating traditional ecological knowledge into contemporary resource management. Paper presented at the 12th World Forestry Congress, Québec City. www.fao.org/DOCREP/ARTICLE/WFC/XII/0887-A3.HTM (accessed 11 Mar 2019)

* Charnley S, Carothers C, Satterfield T, Levine A and others (2017) Evaluating the best available social science for natural resource management decision-making. Environ Sci Policy 73:80-88

Chittleborough RG (1965) Dynamics of two populations of the humpback whale, Megaptera novaeangliae (Borowski). Mar Freshw Res 16:33-128

Cinner JE, Daw TM, McClanahan TR, Muthiga N and others (2012) Transitions toward co-management: the process of marine resource management devolution in three east African countries. Glob Environ Change 22:651-658
Commonwealth of Australia (1999) Environment Protection and Biodiversity Conservation Act. Australian Government, Department of the Environment and Energy, Canberra

Commonwealth of Australia (2015) Wildlife Conservation Plan for Migratory Shorebirds. Australian Government, Department of the Environment and Energy, Canberra

Commonwealth of Australia (2017a) Australian National Guidelines for Whale and Dolphin Watching 2017. Australian Government, Department of the Environment and Energy, Canberra. www.environment.gov.au/system/ files/resources/7f15bfc1-ed3d-40b6-a177-c81349028ef6/ files/aust-national-guidelines-whale-dolphin-watching2017.pdf (accessed 8 Aug 2017)

Commonwealth of Australia (2017b) Recovery Plan for Marine Turtles in Australia. https://www.environment. gov.au/system/files/resources/46eedcfc-204b-43de-99c54d6f6e72704f/files/recovery-plan-marine-turtles-2017.pdf (accessed 15 Nov 2017)

Corbin J, Strauss A (1990) Grounded theory research: procedures, canons, and evaluative criteria. Qual Sociol 13: $3-21$

Craik W (2018) Review of interactions between the EPBC Act and the agriculture sector. https://www.environment. gov.au/epbc/information-for/farmers/agriculture-review (accessed 1 Oct 2018)

* Cvitanovic C, Cunningham R, Dowd AM, Howden SM, van Putten EI (2017) Using social network analysis of knowledge brokers at connecting scientists and decision-makers: an Australian case study. Environ Policy Gov 27: 256-269

* Dale A, Vella K, Potts R (2013) Governance systems analysis (GSA): a framework for reforming governance systems. J Public Adm Gov 3:162-187

Dale A, George M, Hill R, Fraser D (2016) Traditional Owners and sea country in the southern Great Barrier Reef which way forward? Report to the National Environmental Science Programme. Reef and Rainforest Research Centre Limited, Cairns

de Loë R, Armitage D, Plummer R, Davidson S, Moraru L (2009) From government to governance: a state-of-theart review of environmental governance. Final report. Prepared for Alberta Environment, Environmental Stewardship, Environmental Relations. Rob de Loë Consulting Services, Guelph, Ontario.

Wepartment of Conservation (2017) Environmental Education for Sustainability Strategy and Action Plan (20172021). https://www.doc.govt.nz/about-us/our-policies-andplans/education-strategies/environmental-education-forsustainability-strategy-and-action-plan/ (accessed $12 \mathrm{Apr}$ 2019)

* Dietz T, Ostrom E, Stern PC (2003) The struggle to govern the commons. Science 302:1907-1912

* Emerson K, Nabatchi T, Balogh S (2012) An integrative framework for collaborative governance. J Public Adm Res Theory 22:1-29

Eshach H (2007) Bridging in-school and out-of-school learning: formal, non-formal, and informal education. J Sci Educ Technol 16:171-190

*Evans ME, Cvitanovic C (2018) An introduction to achieving policy impact for early career researchers. Palgrave Commun 4:88

Folke C, Hahn T, Olsson P, Norberg J (2005) Adaptive governance of social-ecological systems. Annu Rev Environ Resour 30:441-473 
Fox HE, Barnes MD, Ahmadia GN, Kao G and others (2017) Generating actionable data for evidence-based conservation: the global center of marine biodiversity as a case study. Biol Conserv 210:299-309

Fraser KA, Adams VM, Pressey RL, Pandolfi JM (2017) Purpose, policy, and practice: intent and reality for onground management and outcomes of the Great Barrier Reef Marine Park. Mar Policy 81:301-311

Fusch PI, Ness LR (2015) Are we there yet? Data saturation in qualitative research. Qualit Rep 20: 408-1416

Gallo-Cajiao E, Morrison TH, Fidelman P, Kark S, Fuller RA (2019) Global environmental governance for conserving migratory species in the Asia-Pacific. Reg Environ Change 19:1113-1129

Garmestani AS, Benson MH (2013) A framework for resilience-based governance of social-ecological systems. Ecol Soc 18:9

Geoscience Australia (2019a) Maritime boundary definitions. www.ga.gov.au/scientific-topics/marine/jurisdiction/ maritime-boundary-definitions (accessed 27 Feb 2019)

Geoscience Australia (2019b) The law of the sea. www.ga. gov.au/scientific-topics/marine/jurisdiction/law-of-thesea (accessed 27 Feb 2019)

Gould RK, Phukan I, Mendoza ME, Ardoin NM, Pannikar B (2017) Seizing opportunities to diversify conservation. Conserv Lett 11:e12431

Graham J, Amos B, Plumptre T (2003) Principles for good governance in the 21st century. Policy Brief No. 15. Institute On Governance, Ottawa

Green AO, Hunton-Clarke L (2003) A typology of stakeholder participation for company environmental decision-making. Bus Strategy Environ 12:292-299

Gumana v Northern Territory (2007) FCAFC 23. https:// jade.io/j/? a=outline\&id=5063 (accessed $21 \mathrm{Feb} 2019$ )

Hansen BD, Clemens RS, Gallo-Cajiao E, Jackson MV and others (2018) Shorebird monitoring in Australia: a successful long-term collaboration among citizen scientists, governments and researchers. In: Legge S, Lindenmayer D, Robinson N, Scheele B, Southwell D, Wintle B (eds) Monitoring threatened species and ecological communities. CSIRO Publishing, Clayton South, p 149-164

*Hawke A (2009) The Australian Environment Act: report of the independent review of the Environment Protection and Biodiversity Conservation Act 1999. https://www. environment.gov.au/legislation/environment-protectionand-biodiversity-conservation-act/epbc-review-2008 (accessed 28 Sep 2017)

Hays GC, Bailey H, Bograd SJ, Bowen WD and others (2019) Translating marine animal tracking data into conservation policy and management. Trends Ecol Evol 34: 459-473

Head B, Ferguson M, Cherney A, Boreham P (2014) Are policy-makers interested in social research? Exploring the sources and uses of valued information among public servants in Australia. Policy Soc 33:89-101

Holling CS (ed) (1978) Adaptive environmental assessment and management. Wiley, Chichester

Howes M (2008) Rethinking governance: lessons in collaboration from environmental policy. Paper for the Australasian Political Studies Association Annual Conference 2008. https://core.ac.uk/download/pdf/143862370. pdf (accessed 9 Apr 2008)

Humane Society International (2018) Next generation biodiversity laws. Prepared by Environment Defenders Office NSW. Submission to the Senate Inquiry on Australia's faunal extinction crisis (Submission 4). https://www. aph.gov.au/Parliamentary_Business/Committees/Senate/ Environment_and_Communications/EPBC_Live_Primates_ Bill/Submissions (accessed 8 Apr 2019)

Imperial MT (1999) Institutional analysis and ecosystembased management: the institutional analysis and development framework. Environ Manage 24:449-465

Jones G (2005) Is the management plan achieving its objectives? In: Worboys G, Lockwood M, De Lacy T (eds) Protected area management: principles and practice, 2nd edn. Oxford University Press, South Melbourne

Jones G (2009) The adaptive management system for the Tasmanian Wilderness World Heritage Area-linking management planning with effectiveness evaluation. In: Allan C, Stankey GH (eds) Adaptive environmental management. Springer, Dordrecht, p 227-258

* Kitzinger J (1994) The methodology of focus groups: the importance of interaction between research participants. Sociol Health Illn 16:103-121

* Lascelles B, Notarbartolo Di Sciara G, Agardy T, Cuttelod A and others (2014) Migratory marine species: their status, threats and conservation management needs. Aquat Conserv 24:111-127

* Leenhardt P, Teneva L, Kininmouth S, Darling E, Cooley S, Claudet J (2015) Challenges, insights and perspectives associated with using social-ecological science for marine conservation. Ocean Coast Manage 115:49-60

* Lemos MC, Agrawal A (2006) Environmental governance. Annu Rev Environ Resour 31:297-325

K Liberal Party of Australia (2019) Our beliefs. https://www. liberal.org.au/our-beliefs (accessed 9 Apr 2019)

Liverman D (2004) Who governs, at what scale, and at what price? Geography, environmental governance, and the commodification of nature. Ann Assoc Am Geogr 94: 734-738

* Lockwood M (2010) Good governance for terrestrial protected areas: a framework, principles and performance outcomes. J Environ Manage 91:754-766

* Luyet V, Schlaepfer R, Parlange MB, Buttler A (2012) A framework to implement stakeholder participation in environmental projects. J Environ Manage 111:213-219

Maarschalk J (1988) Scientific literacy and informal science teaching. J Res Sci Teach 25: 135-146

Mace GM (2014) Whose conservation? Science 345:1558-1560

Macintosh A (2010) Best practice environmental impact assessment: a model framework for Australia. Aust J Public Adm 69:401-417

Margerum RD (2008) A typology of collaboration efforts in environmental management. Environ Manage 41:487-500

* Marin A, Berkes F (2010) Network approach for understanding small-scale fisheries governance: the case of the Chilean coastal co-management system. Mar Policy 34: 851-858

Marsh H, Lefebvre LW (1994) Sirenian status and conservation efforts. Aquat Mamm 20:155-170

*Marsh H, Eros C, Corkeron P, Breen B (1999) A conservation strategy for dugongs: implications of Australian research. Mar Freshw Res 50:979-990

* McCay BJ, Micheli F, Ponce-Díaz G, Murray G and others (2014) Cooperatives, concessions, and co-management on the Pacific coast of Mexico. Mar Policy 44:49-59

McDonald JA, Carwardine J, Joseph LN, Klein CJ and others (2015) Improving policy efficiency and effectiveness to save more species: a case study of the megadiverse country Australia. Biol Conserv 182:102-108 
Meek CL, Lovecraft AL, Varjopuro R, Dowsley M, Dale AT (2011) Adaptive governance and the human dimensions of marine mammal management: implications for policy in a changing north. Mar Policy 35:466-476

Mees HLP, Uittenbroek CJ, Hegger DLT, Driessen PPJ (2019) From citizen participation to government participation: an exploration of the roles of local governments in community initiatives for climate change adaptation in the Netherlands. Environ Policy Gov 29:198-208

Meynecke JO, Vindenes S, Teixeira D (2013) Monitoring humpback whale (Megaptera novaeangliae) behaviour in a highly urbanised coastline: Gold Coast, Australia. In: Moksness E, Dahl E, Støtrupp J (eds) Global challenges in integrated coastal zone management. Wiley-Blackwell, Chichester, p 101-113

Miller RL, Marsh H, Cottrell A, Hamann M (2018) Protecting migratory species in the Australian marine environment: a cross-jurisdictional analysis of policy and management plans. Front Mar Sci 5:229

Miller RL, Marsh H, Benham CF, Hamann M (2019) A framework for improving the cross-jurisdictional collaborative governance of a marine migratory species. Conserv Sci Pract 1:e58

Morrison TH (2017) Evolving polycentric governance of the Great Barrier Reef. Proc Natl Acad Sci USA 114: E3013-E3021

Mostert E, Pahl-Wostl C, Reese Y, Searle B, Tàbara D, Tippett $\mathrm{J}$ (2007) Social learning in European river-basin management: barriers and fostering mechanisms from 10 river basins. Ecol Soc 12:19

Mountjoy NJ, Seekamp E, Davenport MA, Whiles MR (2014) Identifying capacity indicators for communitybased natural resource management initiatives: focus group results from conservation practitioners across Illinois. J Environ Plann Manage 57:329-348

Murray-Darling Basin Authority (2019) Fish deaths in the Lower Darling. https://www.mdba.gov.au/managingwater/drought-murray-darling-basin/fish-deaths-lowerdarling (accessed 16 Aug 2019)

Nevins HM, Adams J, Moller H, Newman J, Hester M, Hyrenback KD (2009) International and cross-cultural management in conservation of migratory species. J R Soc N Z 39:183-185

Newig J, Gunther D, Pahl-Wostl C (2010) Synapses in the network: learning in governance networks in the context of environmental management. Ecol Soc 14:24

Noad MJ, Paton D, Cato D (2011) Absolute and relative abundance estimates of Australia east coast humpback whales (Megaptera novaeangliae). J Cetacean Res Manag 3:243-252

Nursey-Bray M, Rist P (2009) Co-management and protected area management: achieving effective management of a contested site, lessons from the Great Barrier Reef World Heritage Area (GBRWHA). Mar Policy 33: 118-127

Oliver K, Cairney P (2019) The dos and don'ts of influencing policy: a systematic review of advice to academics. Palgrave Commun 5:21

Olsson P, Folke C, Galaz V, Hahn T, Schultz L (2007) Enhancing the fit through adaptive co-management: creating and maintaining bridging functions for matching scales in the Kristianstads Vattenrike Biosphere Reserve, Sweden. Ecol Soc 121:28

Ostrom E (1986) A method of institutional analysis. In: Kaufmann FX, Majone G, Ostrom V (eds) Guidance, control, and evaluation in the public sector. Walter de Gruyter, New York, NY, p 501-523

Patton M (1990) Qualitative evaluation and research methods. Sage, Beverly Hills, CA

* Pietri DM, Stevenson TC, Christie P (2015) The Coral Triangle Initiative and regional exchanges: strengthening capacity through a regional learning network. Glob Environ Change 33:165-176

* Plummer R, Armitage DR, de Loë RC (2013) Adaptive comanagement and its relationship to environmental governance. Ecol Soc 18:21

* Potts R, Vella K, Dale A, Sipe N (2016) Evaluating governance arrangements and decision making for natural resource management planning: an empirical application of the governance systems analysis framework. Soc Nat Resour 29:1325-1341

Q Queensland Conservation Council (2018) Submission to the Senate inquiry on Australia's faunal extinction crisis (Submission 43). https://www.aph.gov.au/Parliamentary_ Business/Committees/Senate/Environment_and_ Communications/Faunalextinction/Submissions (accessed 8 Apr 2019)

Rabiee F (2004) Focus-group interview and data analysis. Proc Nutr Soc 63:655-660

* Reed MS, Graves A, Dandy N, Posthumus H and others (2009) Who's in and why? A typology of stakeholder analysis methods for natural resource management. J Environ Manage 90:1933-1949

Riskas KA, Fuentes MMPB, Hamann M (2016) Justifying the need for collaborative management of fisheries bycatch: a lesson from marine turtles in Australia. Biol Conserv 196:40-47

Rose K (1994) Unstructured and semi-structured interviewing. Nurse Res 1:23-32

* Rowe G, Frewer L (2000) Public participation methods: a framework for evaluation in science. Technol Human Values 25:3-29

S Sunderland T, Sunderland-Groves J, Shanley P, Campbell B (2009) Bridging the gap: How can information access and exchange between conservation biologists and field practitioners be improved for better conservation outcomes? Biotropica 41:549-554

Sutton S (2004) Outdoor recreation planning frameworks: an overview of best practices and comparison with Department of Conservation (New Zealand) planning processes. In: Smith KA, Schott C (eds) Proc New Zealand Tourism Hosp Res Conf, Wellington, 8-10 Dec 2004. Victoria University of Wellington, p 407-423

* Szabo JK, Choi CY, Clemens RS, Hansen B (2016) Conservation without borders - solutions to declines of migratory shorebirds in the East Asian-Australasian flyway. Emu 116:215-221

* Tamir P (1991) Factors associated with the relationship between formal, informal, and nonformal science learning. J Environ Educ 22:34-42

* Tear TH, Kareiva P, Angermeier PL, Comer P and others (2005) How much is enough? The recurrent problem of setting measurable objectives in conservation. Bioscience 55:835-849

* Teddlie C, Yu F (2007) Mixed methods sampling: a typology with examples. J Mixed Methods Res 1:77

Termeer CJAM, Dewulf A, van Lieshout M (2010) Disentangling scale approaches in governance research: comparing monocentric, multilevel, and adaptive governance. Ecol Soc 15:29 
Threatened Species Scientific Committee (2018) Submission to the Senate inquiry on Australia's faunal extinction crisis (Submission 151). https://www.aph.gov.au/Parliamentary_ Business/Committees/Senate/Environment_and_ Communications/Faunalextinction/Submissions (accessed 25 Oct 2018)

Vilkins S, Grant WJ (2017) Types of evidence cited in Australian Government publications. Scientometrics 113: 1681-1695

Waldron A, Mooers AO, Miller DC, Nibbelink N and others (2013) Targeting global conservation funding to limit immediate biodiversity declines. Proc Natl Acad Sci USA 110:12144-12148

Waldron A, Miller DC, Redding D, Mooers A and others (2017) Reductions in global biodiversity loss predicted from conservation spending. Nature 551:364

Walsh JC, Watson JEM, Bottrill MC, Joseph LN, Possingham HP (2013) Trends and biases in the listing and recovery planning for threatened species: an Australian case study. Oryx 47:134-143

Weiss KC (2011) Towards social-ecological resilience in natural resource governance: issues of power, diversity and scale. PhD thesis, James Cook University, Townsville

Weiss K, Hamann M, Kinney M, Marsh H (2012) Knowledge

Editorial responsibility: Rebecca Lewison,

San Diego, California, USA exchange and policy influence in a marine resource governance network. Glob Environ Change 22:178-188

*Whiting LS (2008) Semi-structured interviews: guidance for novice researchers. Nurs Stand 22:35-40

Wintle BA (2018) Why, what, how much, and is it worth it? In: Legge S, Lindenmayer DB, Robinson NM, Scheele BC, Southwell DM, Wintle BC (eds) Monitoring threatened species and ecological communities. CSIRO Publishing, Clayton South, p 211-224

*Woinarski JCZ, Garnett ST, Legge SM, Lindenmayer DB (2017) The contribution of policy, law, management, research, and advocacy failings to the recent extinctions of three Australian vertebrate species. Conserv Biol 31: $13-23$

Woodley S, Williams DMcB, Harvey T, Jones A (2006) World Heritage research: making a difference. CRC Reef Research, Education and Capacity Building 1999-2006. CRC Reef Research Centre, Townsville

Young O (2002) The institutional dimensions of environmental change: fit, interplay, and scale. MIT Press, Cambridge, MA

K Zurba M (2009) Bringing local synthesis into governance and management systems: the Girringun TUMRA case in northern Queensland, Australia. J R Soc N Z 39:179-182

Submitted: September 11, 2019; Accepted: June 19, 2020 Proofs received from author(s): August 22, 2020 